\title{
Podridão Pós-Colheita de Cenoura Causada por Ceratocystis fimbriata
}

\author{
Aldir O. Carvalho ${ }^{1} \&$ Margarida G. F. Carmo ${ }^{2}$ \\ Universidade Federal Rural do Rio de Janeiro, ${ }^{1}$ Departamento de Entomologia e Fitopatologia, IB; \\ ${ }^{2}$ Departamento de Fitotecnia, IA, CEP 23.851-970, Seropédica, RJ, e-mail: gorete@ufrrj.br
}

(Aceito para publicação em 30/09/2002)

Autor para Correspondência: Margarida Goréte F. do Carmo

\begin{abstract}
Post harvest decay of carrot caused by Ceratocystis fimbriata

The occurrence of post harvest decay on carrot (Daucus

carotae) caused by Ceratocystis fimbriata is reported for the first time in Brazil.
\end{abstract}

Podridões nas raízes de cenoura (Daucus carota L.) podem ocorrer em condições de campo devido à infecção por Sclerotinia sclerotiorum (Lib.) de Bary ou Sclerotium rolfsii Sacc. ou pela bactéria Erwinia carotovora subsp. carotovora (Jones) Bergey et al. Perdas pós-colheita estão freqüentemente associadas a Erwinia spp., principalmente quando as raízes são colhidas em solos com alto teor de umidade e/ou, não são adequadamente secas após a lavagem. No Rio de Janeiro, RJ, especialmente em mercados da Zona Oeste, foram observados sintomas de podridão de raízes de cenoura distintos daqueles citados na literatura. As lesões se iniciavam em pequenos pontos e progrediam rapidamente culminando com podridão das raízes acompanhada de escurecimento da superfície das lesões e formação de cancros à medida que as raízes perdiam a turgescência (Figura 1A,B). As primeiras constatações foram feitas em novembro de 2000 e se mantiveram em altos níveis até março de 2001 , causando perdas de até $40 \%$ por caixa. Amostras de raízes com os sintomas des critos foram levadas ao laboratório na UFRRJ. Após observações em microscópio estereoscópico e ótico constataram-se conídios, clamidosporos e peritécios característicos de Ceratocystis sp. Após isolamento do fungo em BDA, efetuaram-se inoculações em raízes de cenoura, cv. Brasília, recém colhidas, e em mudas de mangueira (Mangifera indica L.) a partir de cultura com dez dias de crescimento a $25^{\circ} \mathrm{C}$. As raízes de cenoura foram inoculadas por meio de deposição de discos de micélio com $4 \mathrm{~mm}$ de diâmetro sobre as raízes previamente feridas pela remoção de fragmentos do córtex e, por atomização de suspensão de conídios $\left(2 \times 10^{4}\right.$ conídios $\left./ \mathrm{ml}\right)$ sobre raízes previamente feridas com escova de cerdas macias e sem ferimento. Em mangueira, os discos foram depositados sobre ramos jovens após retirada da casca com auxílio de canivete. Simultaneamente, inocularam-se raízes de cenoura com discos de micélio de $S$. sclerotiorum e suspensão de células de E. carotovora subsp. carotovora. As raízes inoculadas, após cinco dias de incubação a $25{ }^{\circ} \mathrm{C}$, reproduziram os mesmos sintomas inicialmente descritos e distintos daqueles resultantes da inoculação com S. sclerotiorum e E. carotovora (Figura 1C). Nas raízes inoculadas por atomização observou-se desenvolvimento das lesões de forma aleatória na superfície das raízes previamente feridas enquanto que nas raízes sem ferimento as lesões desenvolveram-se a partir dos pontos de emissão de raízes secundárias e de pequenas fissuras. As mudas de mangueira inoculadas igualmente desenvolveram sintomas de necrose na região inoculada e adjacências. Observações em microscópio estereoscópico e ótico evidenciaram a presença das fases teliomórfica (peritécios globosos, escuros, ostiolado e com longo pescoço que termina com franjas de hifas ostiolares) e anamórfica (conídios enteroblásticos e clamidosporos globosos, marrons escuros) (Figura 1D, E e F) típicos de Ceratocystis fimbriata Ell. e Haslt. (Wingfield et al. Ceratocystis and Ophiostoma, APS Press 1993). Este é o primeiro relato de ocorrência de $C$. fimbriata em raízes de cenoura.

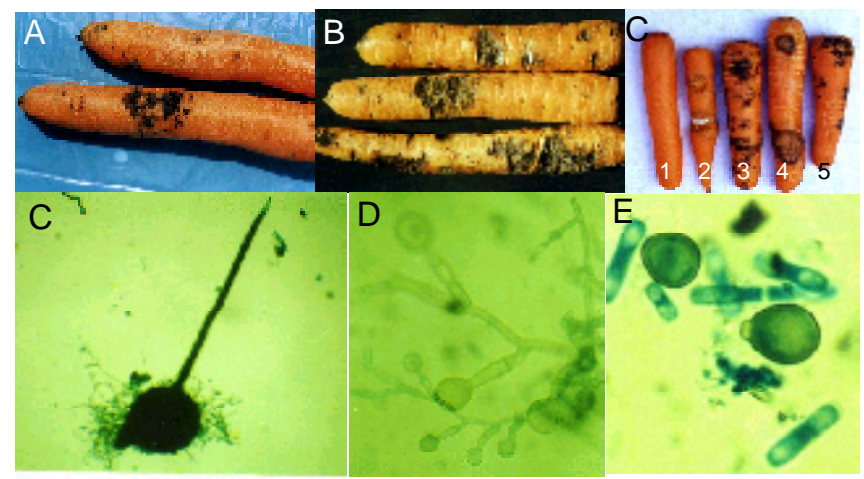

FIG. 1 - Início e progresso da podridão negra em raízes de cenoura (Daucus carota) (A) culminando com a formação de cancros $(B)$; testemunha sadia (C1), sintoma devido à inoculação por Sclerotinia sclerotiorum (C2), por Ceratocystis fimbriata (C3), por Erwinia carotovora ssp. carotovora (C4), e devido à infecção natural por $C$. fimbriata (C5); peritécio de $C$. fimbriata (D); formação de clamidosporos (E) e conídios e clamidosporos da fase anamórfica de $C$. fimbriata.(F). 